\title{
O LÚDICO NO DISCURSO DE PROFESSORES NA EDUCAÇÃO INFANTIL
}

\section{THE PLAYFULNESS IN THE TEACHERS 'SPEECH IN CHILDHOOD EDUCATION}

\section{LO LÚDICO EN EL DISCURSO DE MAESTROS EN LA EDUCACIÓN INFANTIL}

\author{
Maria Roseane Alves VELEZ ${ }^{1}$ \\ Cristiane Navarrete TOLOMEI ${ }^{2}$
}

1. Pedagoga. Mestre em Ciências da Educação. E-mail: roseane_velez@hotmail.com

2. Doutora em Letras pela Universidade de São Paulo. Docente Adjunto III do curso de Letras na Universidade Federal do Maranhão, Campus Bacabal; Docente Permanente no Programa de Pós-Graduação em Letras (PGLB/UFMA/Bacabal) e no Programa de Pós-Graduação em Cultura e Sociedade (PGCult/UFMA/ São Luís). E-mail: cntolomei@yahoo.com.br

RESUMO: Objetivou-se analisar de que modo os professores compreendem o lúdico no processo de ensino e sua relevância para a aprendizagem em uma creche pública do município de Queimadas-PB. Tratou-se de uma pesquisa qualitativa com método de procedimento exploratório-descritivo, onde se empregou questionários com questões abertas e fechadas aplicadas a nove professoras. As análises dos resultados apontaram que as participantes da pesquisa compreendem o processo de desenvolvimento infantil e reconhecem a importância da ludicidade em suas práticas pedagógicas, no processo de ensino e aprendizagem. O estudo indicou que as participantes possuem conhecimentos adquiridos que asseguram as suas ações educativas lúdicas. As investigações, segundo o referencial teórico e afirmações das docentes, levaram-nos a concluir a necessidade de uma reestruturação ou uma formação aprofundada quanto a práticas pedagógicas relacionadas aos conhecimentos da Base Nacional Comum Curricular, indicando, portanto, a necessidade de capacitar essas professoras atuantes e as gerações futuras, sobre essa nova perspectiva de referencial, bem como tomarem conhecimento $\mathrm{e}$ utilizarem nas suas mediações pedagógicas.

Palavras-chave: Ludicidade. Creches Aprendizagem. Crianças. BNCC.

\begin{abstract}
The objective was to analyze how teachers understand playfulness in the teaching process and its relevance for learning in a public daycare center in the municipality of QueimadasPB. It was a qualitative research with an exploratory-descriptive procedure method, where questionnaires with open and closed questions applied to nine teachers were used. The analysis of the results showed that the research participants understand the child development process and recognize the importance of playfulness in their pedagogical practices, in the teaching and learning process. The study indicated that the participants have acquired knowledge that ensures their playful educational actions. The investigations, according to the theoretical framework and statements of the teachers, led us to conclude the need for a restructuring or indepth training regarding pedagogical practices related to the knowledge of the Common National Curricular Base, indicating, therefore, the need to train these active teachers and future generations, about this new perspective of reference, as well as getting to know and use it in their pedagogical mediations.
\end{abstract}

Keywords: Playfulness. Nurseries. Learning. Children. BNCC.
RESUMEN: El objetivo fue analizar cómo los docentes entienden el lúdico en el proceso de enseñanza y su relevancia para el aprendizaje en una guardería pública del municipio de Queimadas-PB. Se trató de una investigación cualitativa con un método de procedimiento exploratorio-descriptivo, donde se utilizaron cuestionarios con preguntas abiertas y cerradas aplicadas a nueve docentes. El análisis de los resultados mostró que los participantes de la investigación comprenden el proceso de desarrollo infantil y reconocen la importancia del ludicidade en sus prácticas pedagógicas, en el proceso de enseñanza y aprendizaje. El estudio indicó que los participantes han adquirido conocimientos que aseguran sus acciones educativas lúdicas. Las investigaciones, de acuerdo con el marco teórico y declaraciones de los docentes, nos llevaron a concluir la necesidad de una reestructuración o capacitación en profundidad en cuanto a prácticas pedagógicas relacionadas con el conocimiento de la Base Curricular Nacional Común, indicando, por tanto, la necesidad de formar a estos docentes activos y futuras generaciones, sobre esta nueva perspectiva de referencia, así como conocerla y utilizarla en sus mediaciones pedagógicas.

Palabras-clave: Ludicidade. Viveros. Aprendizaje. Niños. BNCC. 


\section{INTRODUÇÃO}

O período escolar é muito importante para que as crianças ampliem suas aprendizagens em diferentes áreas do seu desenvolvimento para que, posteriormente, venha ter capacidade ou estar mais preparada para enfrentar a realidade, e as outras etapas da vida escolar futura.

Neste sentido, nós educadores, devemos incrementar atividades que proporcionem às crianças o desenvolvimento de capacidades necessárias para que elas construam o seu conhecimento, e possam envolver-se totalmente na comunidade escolar.

A escola é o espaço principal e responsável por formar cidadãos conscientes e responsáveis, que demonstrem sentido crítico, sejam sensíveis a mudanças e mostrem respeito por si próprio e, sobretudo, pelos outros, desde o grupo de pares, a professores e funcionários. E a educação com base numa perspectiva lúdica permite aos alunos momentos dinâmicos, interessantes e completos de motivação, que vão potencializar as competências acadêmicas, nomeadamente o que diz respeito à leitura e à escrita.

Para a pesquisa, priorizamos as professoras no exercício do magistério, no sentido de identificar como compreendem a ludicidade no desenvolvimento e aprendizagem na Educação infantil e a relevância que ele tem no ensino. Foram levantadas questões sobre a ludicidade na prática pedagógica dos professores, se na formação ela foi enfatizada e se na prática eles veem a importância da ludicidade e as contribuições da mesma no contexto da Educação Infantil.

A pesquisa fundamentou-se por meio de documentos oficiais como a BNCC (Base Nacional Comum Curricular), RCNEI (Referencial Curricular Nacional para a Educação Infantil), LDB (Lei de Diretrizes e Bases da Educação Nacional) e DCNEI (Diretrizes Curriculares Nacionais da Educação Infantil); e com teóricos que abordam essa temática como Vygotsky (1994), Piaget (1978) Áries (1986), Kishimoto (2010), Moyles (2002) dentre outros.

Para obtenção dos dados, priorizamos a aplicação de questionários contendo questões abertas e fechadas. Um instrumento valioso que permite a integridade da investigação.

Torna-se assim relevante essa pesquisa, pois é preciso compreender o papel da ludicidade, enquanto professores mediadores, contribuindo para a formação integral de nossas crianças. É uma possibilidade de reflexão, tanto para professores em ação como para nós alunos, em torno da nossa formação acadêmica, possibilitando e favorecendo deste modo o desenvolvimento das crianças de maneira prazerosa e eficaz.

Desta forma, pretendeu-se analisar de que modo professores entendem o lúdico no processo de ensino e aprendizagem na Educação Infantil na creche pública do município de Queimadas-PB.

\section{METODOLOGIA}

Tendo em conta os objetivos do estudo, a metodologia que foi proposta, a natureza qualitativa, o caráter predominantemente intensivo, e com o recurso ao método de estudo de casos múltiplos, a metodologia qualitativa fundamentou-se num paradigma naturalista, na medida em que a realidade educativa é extremamente complexa e 
só uma visão holística da dela pode garantir a compreensão alargada do processo ensino-aprendizagem. Esta metodologia apresentou-se como descritiva e interventiva numa orientação didática e formativa.

Seguindo um caráter intensivo, tratou de um fenômeno específico e aprofunda a informação recolhida, valorizando o sentido que os agentes sociais conferem à ação. Com este método mais específico, permitiu-nos aprofundar mais a observação, valorizar o quotidiano da amostra e as suas formas de expressão no momento em que realizam as atividades propostas.

O estudo representou a "estratégia preferida quando se colocam questões do tipo 'como' e 'por quê', quando o pesquisador tem pouco controle sobre os eventos e quando o foco se encontra em fenômenos contemporâneos inseridos em algum contexto da vida real" (Yin, 2005, p. 19), uma vez que permite "uma investigação para se preservar as características holísticas e significativas dos eventos da vida real" (YIN, 2005, p. 21).

A metodologia que usamos envolveu estudo de casos múltiplos, em que cada caso foi selecionado por se preverem resultados semelhante ou que contrastassem. Yin (2005, p. 68) afirma que estes costumam ser mais convincentes e ressalta ainda, que um estudo de caso múltiplo para ser bem-sucedido deve obedecer a uma lógica de replicação e não a da amostragem.

A pesquisa foi descritiva à medida que utilizou o método indutivo e envolveu técnicas padronizadas de coleta de dados, onde permitiu-se descrever os fatos e fenômenos de determinada realidade sem, porém, interferir/alterar quaisquer dados, tendo a utilização de questionários.

A finalidade dos questionários com questões abertas e fechadas, dirigidos às professoras da creche foi conhecer suas práticas pedagógicas voltadas para a ludicidade, a partir de suas concepções e opiniões. Para isso foram elaboradas 19 (dezenove) questões, de caráter subjetivo, possibilitando assim um vínculo de conhecimento entre as pessoas envolvidas.

Nossa pesquisa em campo foi realizada na Creche da cidade de Queimadas-PB na modalidade da Educação Infantil com crianças de 1 até 4 anos de idade. Localizada na cidade de Queimadas-Paraíba, e os participantes dessa pesquisa foram às próprias professoras da Creche. No intento de preservar a identidade das participantes, omitiu-se suas identidades.

Segundo Orlandi (1999), a linguagem é um instrumento de relação social bastante estudada por diversas áreas de pesquisa. Pode ser analisada sob a forma de um sistema que permite que cada elemento que a compõe possua diferentes significados mediante ao contexto em que está inserido. Além disso, pode ser tomada como um conjunto de regras formais, no qual se estuda tanto as diferentes variações históricas que ocorreram e transformaram as línguas, bem como as tendências futuras de cada uma delas. Trata-se, portanto, de uma faculdade organizada pela língua em sistemas fônicos, gestos, mímicas e diferentes expressões corporais, capaz de materializar o pensamento e permitir com que o "sujeito" consiga expressar aquilo que pensa.

As análises referentes à ludicidade no processo de desenvolvimento e aprendizagem das crianças na Educação Infantil teviveram como suporte teórico as contribuições dos vários autores mencionados, como Kramer (2009), Kishimoto (2010), Vygotsky (1989), Piaget (1973), Freire (2002), entre outros e a partir da LBD, das Diretrizes Curriculares Nacionais para a Educação Infantil (DCNEI's), do Referencial Curricular Nacional para a 
Educação Infantil (RCNEI), a Base Nacional Comum Curricular (BNCC) dentre outras referências, tendo enfoques na temática a ser trabalhada.

A pesquisa foi realizada com nove professoras entre elas efetivas e contratadas, que atuam especificamente no turno da manhã, as professoras lecionam na modalidade da Educação Infantil, e ensinam em turmas variadas, entre Berçário (1 ano), Maternal I ( 2 anos de idade) e Maternal II (de 3 até 4 anos de idade), porém participaram da pesquisa apenas as professoras que trabalham no Maternal II no período da manhã, em uma creche da rede pública, localizada no município de Queimadas-PB.

A critério da pesquisadora as participantes da pesquisa foram denominadas, na ordem em que foram entregues os questionários, como P1, P2, assim sucessivamente, na ordem de entrega. Foram atribuídos os códigos P1, P2, P3, P4, P5, P6, P7, P8, P9 para todos os professores que fizeram parte da pesquisa, garantindo assim o direito ao anonimato e sigilo dos nomes, não exposto nenhuma das professoras pesquisadas.

A coleta de dados foi realizada em maio de 2019 e deu-se inicialmente a partir da pesquisadora que se dirigiu ao local escolhido, sendo uma creche pública do município de Queimadas-PB. Apresentou no primeiro dia de visita a proposta de trabalho, ganhando assim a permissão da diretora e confirmando a participação das professoras do turno da manhã. No segundo dia foi lido o Termo de Consentimento Livre e esclarecido (TCLE), sendo entregue e assinado previamente pelos professores, e foi discutido a temática e as devidas orientações sobre os questionários que seriam aplicados aos professores da creche, e deu-se início a aplicação de alguns questionários.

No terceiro dia voltou-se a creche novamente para realizar os questionários de alguns professores que não foram aplicados. Recolhemos todos os questionários respondidos nesse dia. Apenas uma professora faltou devolver o questionário, assim voltou-se novamente no quarto dia para realizar apenas esse questionário, porém a professora recusou a devolver o questionário e participar da pesquisa.

Para aplicação dos questionários a diretora da creche disponibilizou a brinquedoteca para que individualmente cada professora fosse prestando sua colaboração com a pesquisa. Assim os questionários foram aplicados e ocorreu de forma individual na dependência da creche. A duração dos questionários foi de aproximadamente quarenta e cinco minutos, e durante este período a pesquisadora se manteve na sala junto com a professora, a pesquisadora não teve acesso para ficar em sala de aula.

Durante todo o processo da pesquisa procuramos acompanhar as etapas propostas Lefebvre (2005) detalhadamente: organização do material coletado, listagem, leitura e interpretação dos dados; releitura dos dados e identificação dos temas pertinentes as questões correspondentes. Em seguida foram vinculados os dados e consideramos os principais elementos importantes (temas). Após, vinculamos os dados segundo os elementos consideráveis, fizemos a separação e organização em blocos de definição para tornar possível a construção das categorias empíricas de investigação. Em todo o processo de estudo, o material foi correlacionado à literatura pertinente para dar apoio à discussão.

\section{RESULTADOS E DISCUSSÃO}


Para a pesquisa foram entregues 9 (nove) questionários aos pesquisados, entretanto, uma das pesquisadas não devolveu o mesmo, sendo assim, a quantidade de pesquisados foram no total 8 (oito).

Foi possível verificar o perfil social dos pesquisados e constatou-se que todos os professores são do sexo feminino. Sobre o perfil profissional dos professores participantes da pesquisa foi identificado que apenas uma professora (P7) ainda não concluiu a graduação. Todas as demais possuem mais de 10 anos de experiência atuando na área de educação, possuem formação em pedagogia e atuam no Maternal II no turno da manhã.

Verificou-se que duas professoras participantes da pesquisa possuem formação acadêmica em outras áreas. É o caso da Professora (P2) que além de pedagogia é formada em Psicologia, e a Professora (P8), que tem a formação em pedagogia, sendo graduada também em serviço social (Quadro 1).

Quadro 1. Perfil profissional dos professores pesquisados por tipo e ano de formação, tempo de atuação na área que leciona. 2019

\begin{tabular}{|c|c|c|c|c|c|}
\hline Pesquisados & $\begin{array}{c}\text { Ano de } \\
\text { Formação }\end{array}$ & $\begin{array}{c}\text { Tempo } \\
\text { de } \\
\text { Atuação }\end{array}$ & Formação Profissional & Pós-Graduação & Ano que leciona \\
\hline P1 & 2017 & 15 anos & Pedagogia & - & Maternal II \\
\hline P2 & 2005 & 28 anos & Psicologia e Pedagogia & $\begin{array}{c}\text { Especialização e } \\
\text { Mestrado }\end{array}$ & Maternal II \\
\hline P3 & 2004 & 22 anos & Pedagogia & Especialização & Maternal II e Berçário (tarde) \\
\hline P4 & 2010 & 11 anos & Pedagogia & Especialização & Maternal II \\
\hline P5 & 2016 & 10 anos & Pedagogia & - & Maternal II e Berçário (tarde) \\
\hline P6 & 2017 & 9 anos & Pedagogia & Especialização & Maternal II \\
\hline P7 & 2019 & 3 anos & Pedagogia & - & Maternal II \\
\hline P8 & 2005 & 12 anos & Pedagogia e Serviço Social & Especialização & Maternal II \\
\hline
\end{tabular}

Sobre a relevância da formação profissional, este estudo corrobora com a pesquisa de Matos (2013) que expressa à extrema importância em capacitar os profissionais da educação. Segundo ele a formação profissional é necessária, pois permiti que o educador execute um trabalho adequado e significativo conduzindo suas aulas em uma proposta que considere as várias singularidades das crianças e suas diferenças desde a faixa etária, até nas diversidades de hábitos, costumes e valores, proporcionando assim um ambiente acolhedor, onde a aprendizagem dos alunos é a principal meta. Portanto, faz-se indispensável uma formação continuada para os profissionais da Educação Infantil, a fim de aprimorar a prática pedagógica.

Nesse sentido, Kramer (2009) vem contribuir, destacando a importância do aperfeiçoamento contínuo e atualização pedagógica dos professores como meio de reelaboração e redefinição do currículo numa perspectiva crítica, bem como na prática cotidiana tornando-se fundamental o acesso aos conhecimentos que vêm sendo produzidos. Seria assim uma possibilidade de renovar, produzir o conhecimento coletivamente, avançando na reflexão e na atuação em sala de aula.

Dando seguimento ao questionário, procuramos verificar a partir das respostas obtidas no Quadro 2, que todas as professoras demonstram ter conhecimento sobre a temática abordada e valorizam nas suas respostas as práticas lúdicas no processo de ensino de aprendizagem. Vale destacar a resposta cedida pela professora (P5) que afirma: "Instrumento de ensino que proporciona um bom desempenho e desenvolvimento integral das crianças". 
Analisando sua resposta, podemos perceber que a pesquisa compreende que a ludicidade não está ligada apenas as atividades que envolvem brincadeiras, como passa tempo e diversão, a participante da pesquisa argumenta e assegura com sua resposta que a ludicidade é um caminho para desenvolver várias habilidades, desde atividades psicomotoras que envolvem o corpo e movimento, como também atividades mais complexas que envolvem as relações afetivas e cognitivas das crianças (FERNADES, 2012).

Dessa forma podemos assegurar que todas as participantes da pesquisa foram unânimes em afirmar que a ludicidade é fundamental no processo de ensino/aprendizagem na Educação Infantil e está diretamente relacionada com o desenvolvimento integral das crianças.

Quadro 2. Conhecimento dos participantes da pesquisa sobre a concepção de Ludicidade. 2019

\begin{tabular}{|c|c|}
\hline Pesquisados & Falas dos Pesquisados \\
\hline P1 & "É necessário para potencializar o ensino e a aprendizagem, principalmente na Educação Infantil”. \\
\hline $\mathbf{P 2}$ & $\begin{array}{l}\text { "Primordial para a criança, onde a mesma amplia seus conhecimentos através dos jogos e brincadeiras, ao } \\
\text { mesmo tempo constrói sua identidade". }\end{array}$ \\
\hline P3 & $\begin{array}{c}\text { "É o fator primordial na aquisição da aprendizagem, pois faz parte do que é própria da criança, por isso, ela } \\
\text { internaliza de modo mais concreto". }\end{array}$ \\
\hline P4 & "Maneira de ensinar e aprender através de jogos, músicas, dança etc." \\
\hline P5 & "Instrumento de ensino que proporciona um bom desempenho e desenvolvimento integral das crianças". \\
\hline P6 & "A ludicidade vem ajudar na aprendizagem das crianças na educação infantil de uma forma prazerosa". \\
\hline P7 & $\begin{array}{c}\text { "A ludicidade deve estar sempre presente no cotidiano escolar o mesmo tem o poder de contribuir no } \\
\text { desenvolvimento infantil". }\end{array}$ \\
\hline P8 & "É essencial é a Base do desenvolvimento infantil". \\
\hline
\end{tabular}

De acordo com Moyles (2002), o trabalho realizado na Educação Infantil apoiado na ludicidade demanda e requer planejamento constante de atividades lúdicas sobre a importância do planejamento de atividades lúdicas. A autora corrobora esclarecendo que esta metodologia promove uma aprendizagem significativa, inovadora e diferenciada, desenvolvendo a autonomia, criatividade, participação e desenvolvimento do educando, é uma forma de valorizar o seu conhecimento prévio.

Ainda segundo Moyles (2002) a ludicidade em situações educacionais, proporciona não só um meio real de aprendizagem como permite também que adultos perceptivos e competentes aprendam sobre as crianças e suas reais necessidades.

A autora esclarece que o professor observando o brincar das crianças deve ser capaz de compreender em que fase do desenvolvimento (quer seja ele cognitivo, social ou afetivo) ela se encontra e deve conseguir utilizar este brincar para promover novas aprendizagens.

Continuando o questionário, procuramos conhecer na pesquisa, a formação inicial dos pesquisados, e sua relação com essa temática durante suas formações. A partir da observação e análise do Quadro 3, podemos assegurar que dentre essas oito docentes, todas garantem nas suas respostas que não foram preparadas o suficiente em seus cursos de formação inicial para trabalhar o lúdico em sala de aula com seus alunos.

Declaram que não tiveram uma preparação adequada, afirmando que deveria ter mais experiências vivenciadas, para desenvolver melhor esse trabalho no cotidiano com as crianças. Diante de suas respostas, afirmam que foi contemplado, porém de maneira superficial, é o caso da respostada professora (P2) que diz: 
“Pouco. Em sua grande maioria apenas teoria. Vivenciar para colocar em sala de aula, quase nenhuma”. Assim, podemos entender que elas também ressaltaram pouco contato com a temática nas suas formações, porém algumas professoras acabaram relatando um pouco mais de suas vivências com a ludicidade nas suas formações, mostrando que foram poucas que vivenciaram a teoria e a prática.

Quadro 3. Opinião dos participantes sobre como foi enfatizado a ludicidade durante a formação acadêmica e de que modo. 2019

\begin{tabular}{|c|c|} 
Pesquisados & Falas dos Pesquisados \\
\hline P1 & "Foi evidenciado através de Teoria e Prática". \\
\hline P2 & "Pouquíssimo. Apenas uma disciplina em que foi oferecida uma oficina de brinquedos. Na didática da \\
matemática confeccionamos bastante jogos".
\end{tabular}

Assim, Wajskop (1995) esclarece que um profissional atento e preparado pode interferir na ampliação do uso de materiais e dos espaços pelas crianças, tornando desta maneira mais fácil o acesso a diferentes conhecimentos, e possivelmente realizará um trabalho pedagógico adequado, prazeroso para as crianças no ambiente escolar. Inclusive uma formação inadequada do profissional, pode interferir na qualidade do ensino, especialmente na aprendizagem das crianças da Educação Infantil.

A Lei de Diretrizes e Bases da Educação Nacional (LBD), Lei n ${ }^{\circ}$ 9.394/96, implica que a ludicidade pode ser utilizada como uma forma de sondar, introduzir ou reforçar os conteúdos, assim os docentes fundamentados nos interesses e necessidades das crianças, pode levar o aluno a sentir satisfação em descobrir um caminho interessante no aprendizado. Assim o caráter lúdico nas formações continuadas dos profissionais da educação, possibilita e facilita as situações corriqueiras do seu trabalho pedagógico.

Sobre a importância de desenvolver seu trabalho pedagógico a partir da ludicidade. Foi possível verificar a partir das respostas cedidas e análise do Quadro 4, que as participantes da pesquisadas acreditam ser relevante o uso de atividades lúdicas, defendendo em suas respostas que essas atividades são frequentes em suas práticas em sala de aula, pelos muitos benefícios que a ludicidade tem no desenvolvimento das crianças. Todas garantiram nas suas respostas que a ludicidade propicia o desenvolvimento de várias habilidades das crianças no ambiente escolar.

Quadro 4. Opinião dos participantes sobre sua atuação e como compreendem a importância da ludicidade no trabalho realizado com as crianças, e de que modo. 2019

\begin{tabular}{|c|c|}
\hline Pesquisados & Falas dos Pesquisados \\
\hline P1 & "Através da ludicidade podemos tornar as aulas mais prazerosas e interessantes". \\
\hline $\mathbf{P 2}$ & $\begin{array}{c}\text { "No desenvolvimento integral da criança, ajudando-a nos aspectos sociais, afetivos } \\
\text { e cognitivos". }\end{array}$ \\
\hline P3 & "Pelo entusiasmo e satisfação". \\
\hline $\mathbf{P 4}$ & "Melhor maneira das crianças aprenderem, ou seja, forma concreta". \\
\hline P5 & "Desenvolvimento da fala, coordenação e interação com os colegas e professoras". \\
\hline P6 & $\begin{array}{c}\text { "A ludicidade da sensação de prazer para as crianças em suas atividades sendo } \\
\text { assim a criança desenvolve e interage com mais facilidade". }\end{array}$ \\
\hline P7 & "É uma das ferramentas importante para inserir o lúdico". \\
\hline
\end{tabular}


Nesse sentido o Referencial Curricular Nacional para Educação Infantil (1998) vem reiterar esclarecendo que educar significa propiciar situações de cuidado, brincadeiras e aprendizagens orientadas de forma integrada e que possam contribuir para o desenvolvimento das capacidades infantis de relação interpessoal de ser e estar com os outros em uma atitude básica de aceitação, respeito e confiança, promovendo assim conhecimentos mais amplos da realidade social e cultural.

Desse modo o RCNEI esclarece que o caráter educativo e lúdico dos jogos e das brincadeiras permite que o grupo se estruture e que as crianças tenham possibilidades constantes de relações de trocas com outras crianças, convívio social, aprendam assim no cotidiano a esperar sua vez, acostume-se a lidar com regras, conscientizando-se que podem ganhar ou perder nas situações lúdicas propostas.

Questionou-se como são desenvolvidas as atividades lúdicas em sala de aula dessas professoras. Nessa questão deixamos um item no questionário, que também solicitava que as docentes esclarecessem ou dessem exemplos de como realizam essas atividades. A partir das respostas cedidas por essas professoras, podemos afirmar que foram destacadas atividades lúdicas tais como: Jogos, música, contação de histórias, brincadeiras, brinquedos dentre outras formas de trabalhar variadas atividades lúdicas por essas docentes descritas no Quadro 5. As participantes da pesquisa associam à ludicidade como uma forma de educação dinâmica, que possibilita trabalhar diversos conteúdos e temáticas diferentes, afirmando assim que pode promover uma educação interdisciplinar e global para as crianças. Defendendo esse argumento enfatizamos a resposta da Professora (P3) que afirmou: "Desde a rodinha de leitura/chamadinha nas atividades dirigidas e espontânea e até na hora da higienização" (Quadro 5). Compreendemos a partir dessa resposta que a ludicidade na prática cotidiana dessa professora, possivelmente é realizada em diversos momentos e possibilitando um aprendizado significativo para a criança.

Quadro 5. Opinião dos participantes sobre de que modo as atividades lúdicas estão presentes em sua sala de aula. 2019

\begin{tabular}{|c|c|}
\hline Pesquisados & Falas dos Pesquisados \\
\hline P1 & $\begin{array}{c}\text { "Através da contação de histórias, utilizando músicas e objetos que despertem interesses. Jogos, } \\
\text { brincadeiras entre outros." }\end{array}$ \\
\hline $\mathbf{P 2}$ & "Nas atividades que envolvem musicalização, jogos e brincadeiras". \\
\hline P3 & $\begin{array}{c}\text { "Desde a rodinha de leitura/chamadinha nas atividades dirigidas e espontânea e até na hora da } \\
\text { higienização". }\end{array}$ \\
\hline P4 & $\begin{array}{l}\text { "O tempo todo fazemos atividades voltadas ao lúdico como musicalização, dramatização com movimentos, } \\
\text { etc.". }\end{array}$ \\
\hline P5 & "Através de jogos e brincadeiras no dia a dia". \\
\hline P6 & "Nas brincadeiras, musicalização e jogos". \\
\hline P7 & "De forma geral". \\
\hline
\end{tabular}


"Com brincadeiras diversas, desenvolvendo as possibilidades motora, cognitivas e psicológicas".

Recorremos nesse sentido a Piaget (1971) que vem esclarecer que o desenvolvimento de vários aspectos da criança inicia-se e pode acontecer por meio da ludicidade, pontuando que a ludicidade é o universo que agrada a criança. O lúdico realiza na criança seus anseios, possibilitando explorar o mundo ao seu redor, tornando importante proporcionar às crianças atividades que promovam e estimulem seu desenvolvimento global, considerando diferentes aspectos da linguagem, do cognitivo, afetivo, social e motor. A ludicidade evidencia uma forma de ferramenta essencial no processo de aprendizagem e desenvolvimento da criança.

Continuando o questionário, procuramos conhecer na pesquisa, quais os tipos de jogos e brincadeiras que são utilizados pelas docentes em sala de aula. A partir das respostas das participantes e análise do Quadro 6, podemos assegurar que as docentes destacaram em suas respostas utilizar: jogos com brinquedos, jogos confeccionados pelas próprias professoras, brinquedos pedagógicos e brinquedos diversos, como bonecos, carrinhos entre outros.

Quadro 6 - Opinião dos participantes da pesquisa sobre que tipos de jogos e brincadeiras utilizam e disponibilizam para as crianças. 2019

\begin{tabular}{|c|c|}
\hline Pesquisados & Falas dos Pesquisados \\
\hline P1 & $\begin{array}{c}\text { "Jogos de dados, amarelinhas, circuitos, brincadeiras de roda, de quebra-cabeças, alinhavos e } \\
\text { massinhas". }\end{array}$ \\
\hline P2 & $\begin{array}{c}\text { "Jogos e brincadeiras que envolvem nossos colegas, frutas, brinquedos, jogos de encaixe, envolvendo } \\
\text { classificações de cores e formas geométricas, etc. bonecas, carros, baldes de areia". }\end{array}$ \\
\hline P3 & "Jogos de encaixe, empilhamento boliche, bola. As brincadeiras mais utilizadas são apenas as de roda". \\
\hline P4 & "Jogos de encaixe, brinquedos pedagógicos, caixa musical, jogos confeccionados, etc". \\
\hline P5 & "Caixa sensação, arremesso, brinquedos de encaixe". \\
\hline P6 & "Jogos de encaixe, de montar (lego) diversos brinquedos, bonecos, carrinhos, bambolês, cones etc". \\
\hline P7 & "Brincadeiras livres onde possam usar da imaginação, socializar com os colegas" \\
\hline P8 & "Brincadeiras que envolvem músicas e danças". \\
\hline
\end{tabular}

Corroboram nesse assunto de jogos, brinquedos e brincadeiras os estudos de Kishimoto (2010) que vem destacar o jogo, o brinquedo e a brincadeira como elementos e termos que terminam se misturando e colaborando nas vivências sociais das crianças. Segundo o autor o uso do brinquedo ou jogo educativo com fins pedagógicos, remete para a relevância desses instrumentos em situações de ensino-aprendizagem e de desenvolvimento infantil. Esclarecendo assim, que os jogos são importantes, pois facilitam a convivência entre as crianças, estabelecem regras, critérios e sentidos para as regras existirem, possibilita assim um convívio mais social.

Trabalhando com jogos, brinquedos e brincadeiras a relação entre aluno e professor pode também fortalecer os laços de afetividade e isso é muito satisfatório para o desempenho de ambos no processo educacional. Ainda na concepção Kishimoto (2010) a utilização dos jogos vai potencializar a exploração e a construção dos conhecimentos, justificando isso devido à motivação interna que o lúdico provoca nas crianças, entretanto pontua que isso só pode acontecer se o trabalho pedagógico causará oferta de estímulos externos, assim a influência de parceiros, bem como a sistematização de conceitos em outras situações que não são apenas jogos. Ele defende que utilizar a forma lúdica (suporte da brincadeira) proporciona e estimula a construção de novos conhecimentos.

Buscamos investigar no questionário a opinião das participantes da pesquisa sobre como as atividades lúdicas podem contribuir para o processo de ensino-aprendizagem de seus alunos. A partir das respostas e análises 
do Quadro 7, podemos afirmar que essas professoras destacaram que a ludicidade é um meio de incentivar a criança, e ajuda a promover a participação e interesse dos alunos.

Quadro 7. Opinião dos participantes sobre como as atividades lúdicas contribuem para o processo ensino-aprendizagem das crianças. 2019

\begin{tabular}{|c|c|}
\hline Pesquisados & Falas dos Pesquisados \\
\hline P1 & $\begin{array}{c}\text { "Despertando interesse pelas atividades, podemos trabalhar a coordenação motora, a leitura, escrita, as } \\
\text { quantidades". }\end{array}$ \\
\hline P2 & $\begin{array}{c}\text { "Contribuem para os conteúdos sejam trabalhados de maneira lúdica contribuindo para o crescimento das } \\
\text { crianças em seus aspectos cognitivos, motores, afetivos e sociais". }\end{array}$ \\
\hline P3 & "Ocorre automaticamente, pelas brincadeiras". \\
\hline $\mathbf{P 4}$ & “Aprendem os conteúdos manuseando jogos concretos, fazendo contagem, encaixe”. \\
\hline P5 & "As crianças gostam, sentem prazer e se envolve e isto facilita o processo de ensino e aprendizagem”. \\
\hline P6 & “Desenvolve o raciocínio lógico, o compartilhar com os colegas o brinquedo, esperar a vez e de cada um”. \\
\hline P7 & $\begin{array}{c}\text { "Desenvolvem habilidades naturais, segurança emocional, contribuindo também para aspectos } \\
\text { formativos". }\end{array}$ \\
\hline P8 & $\begin{array}{c}\text { "No desenvolvimento psicomotor e cognitivo, bem como as crianças aprendem a seguir combinados e } \\
\text { regras sociais". }\end{array}$ \\
\hline
\end{tabular}

Defendendo essa afirmação enfatizamos a resposta cedida pela Professora (P3) que afirmou: "Ocorre automaticamente, pelas brincadeiras". Compreendemos que a ludicidade é sim, um caminho ou uma alternativa, para incentivar o interesse e participação da criança nas diversas atividades, e também acreditamos que pode promover o ensino e aprendizagem, porém ressaltamos que sem a mediação do professor, sem o planejamento das atividades e sem sistematização, podem-se tornar apenas atividades de diversão, e entretenimento. Devemos entender então que o caráter lúdico contribui para o ensino e aprendizagem, porém essa aprendizagem advém da mediação que o professor realiza com suas crianças.

Partindo desse aspecto Falcão (2002) analisa que as atividades lúdicas fazem com que a criança consiga aprender com mais motivação, satisfação e alegria, porém ele também ressalta que a educação lúdica está longe apenas do ponto de vista de diversão ou distração, ele explica que a educação lúdica é uma ação inerente na criança e vai surgir como uma forma transacional em direção a algum conhecimento, que pode se definir na elaboração constante do pensamento individual em trocas constantes com o pensamento coletivo. Ele também ressalta que a criança brincando com o mundo, aprende sobre ele e amplia a imaginação, a criatividade e a atenção. Assim a ludicidade além de tornar o ensino prazeroso, torna-se importante na construção de novos conhecimentos.

Dando continuidade aos questionamentos, procuramos conhecer das participantes da pesquisa quais são as maiores dificuldades enfrentadas por elas para trabalhar de forma lúdica em sala de aula ou em espaços diferentes. Com base nas respostas obtidas, é possível afirmarmos que a maior dificuldade encontrada por essas professoras é a falta de investimento em material diversificado. Assim a Professora (P7) afirmou: "falta de material para dar um suporte maior" (Quadro 8).

Analisando a maioria das respostas desse quadro, é possível perceber que essas professoras enfatizam que os materiais diversificados ajudariam a realizar uma melhor prática e aulas diferenciadas para seus alunos. Ressaltamos também, mais uma resposta que chamou nossa atenção, a resposta cedida pela Professora (P5), que afirmou: "Sair da zona de conforto, e tempo para pesquisas e planejamento diário tem sido a minha maior 
dificuldade" (Quadro 8). A partir dessa resposta podemos promover uma reflexão sobre a importância do planejamento do professor principalmente nas atividades lúdicas. A resposta cedida pela professora (P5), mostra que o esforço e a busca de novos conhecimentos e o planejamento das atividades que são desenvolvidas para as crianças vão contribuir de forma efetiva para a o ensino e aprendizagem mais do que apenas material diversificado. Segundo essa professora sair da zona de conforto significa então, sair do comodismo e procurar meios de desenvolver suas aulas cada dia melhor, envolvendo a ludicidade.

Quadro 8 - Opinião dos participantes sobre quais são as dificuldades enfrentadas para trabalhar de forma lúdica em sala de aula. 2019

\begin{tabular}{|c|c|}
\hline Pesquisados & Falas dos Pesquisados \\
\hline P1 & "As vezes faltam recursos". \\
\hline P2 & (Não respondeu). \\
\hline P3 & "A escassez de material diversificado, a faixa etária distinta e as particularidades de cada um". \\
\hline P4 & "Material pedagógico, buscar novas maneiras de produzir, e nem sempre a criatividade está em alta". \\
\hline P5 & "Sair da zona de conforto, e tempo para pesquisas e planejamento diário é a minha maior dificuldade". \\
\hline P6 & "Infelizmente falta de material diversificado". \\
\hline P7 & "Falta de material para dar um suporte maior". \\
\hline P8 & (Não respondeu). \\
\hline
\end{tabular}

Segundo as DCNEI's (2009) no artigo 4º é destacado que as propostas pedagógicas da Educação Infantil deverão considerar que a criança é o centro do planejamento curricular, sendo assim é "sujeito" histórico e de direitos que nas interações, relações e práticas cotidianas que vivencia, constrói sua identidade pessoal e coletiva, brinca, imagina, fantasia, deseja, aprende, observa, experimenta, narra, questiona e constrói sentidos sobre a natureza e a sociedade, produzindo assim, cultura e conhecimento. Dessa forma essas interações demostram que o trabalho do professor é fazer uma mediação organizada, planejada e sistemática, cabendo assim, a professora responsabilidade de organizar seu trabalho pedagógico considerando a criança como o centro do seu planejamento.

Corsino (2009, p. 119), também contribui destacando que o planejamento é o momento de reflexão do professor, que a partir das suas observações e registros, possibilita prevê ações, encaminhamentos e sequências de atividades, organiza o tempo e espaço da criança na Educação Infantil. Nesse sentido o autor esclarece que planejar é firmar um compromisso com as crianças no seu processo de ensino e de desenvolvimento.

Sobre como suas formações contribuíram com sua prática atual. Diante das respostas cedidas pelas professoras expostas no Quadro 9, podemos afirmar que suas formações e seus conhecimentos adquiridos ao longo de suas trajetórias acadêmicas contribuíram para que elas descobrissem a importância que a ludicidade apresenta na Educação Infantil, suas respostas mostraram que sabem o quanto é importante trabalhar na prática com as crianças a ludicidade. Enfatizamos a resposta cedida pela Professora (P2) que afirmou: "Participei de seminários e simpósios envolvendo a ludicidade. Adquiri maiores conhecimento, o que ajudou na conscientização de alguns, pois que via a ludicidade de forma equivocada" (Quadro 9). Assim pode-se entender que a ludicidade é fortemente destacada no cenário atual, e também vem sendo discutida tentando atualizar novos conhecimentos na atualidade.

Quadro 9. Opinião dos participantes sobre como a sua formação docente contribuiu com sua prática atual para trabalhar a "ludicidade". 2019

\begin{tabular}{|c|c|}
\hline Pesquisados & Falas dos Pesquisados \\
\hline P1 & "Mostrou a importância e como essa prática favorecia a aprendizagem”. \\
\hline
\end{tabular}




\begin{tabular}{|c|c|}
\hline P2 & $\begin{array}{c}\text { "Participei de seminários e simpósios envolvendo a ludicidade. Adquiri maiores conhecimento, o que ajudou } \\
\text { na conscientização de alguns, pois que via a ludicidade de forma equivocada". }\end{array}$ \\
\hline $\mathbf{P 3}$ & $\begin{array}{l}\text { "Pouco que essa temática foi abordada, resumiu-se mais em questões teóricas, para que o professor venha } \\
\text { desenvolver esse aspecto na prática deve buscar se reciclar e participei de formação continuada". }\end{array}$ \\
\hline P4 & "Tivemos uma disciplina que ajudou a dar um pouco de entendimento". \\
\hline P5 & $\begin{array}{c}\text { "Meu olhar para com as crianças em seu processo de desenvolvimento e aprendizagem. Hoje utilizo mais } \\
\text { momentos de ludicidade no dia a dia". }\end{array}$ \\
\hline P6 & "Veio acrescentar naquilo que acredito que é: aprender brincando é muito prazeroso". \\
\hline P7 & $\begin{array}{c}\text { "Tive poucos momentos, onde foi abordado... mas o pouco que pude observar, tenho uma boa visão quanto } \\
\text { sua contribuição, assim coloco em prática, sempre que possível". }\end{array}$ \\
\hline P8 & "Não. Há um distanciamento entre teoria e prática". \\
\hline
\end{tabular}

Segundo o RCNEI (2009) deve-se assegurar a necessidade de realizar um trabalho de educar e de cuidar em todas as instituições que oferecem a modalidade de Educação Infantil de maneira integrada. Na perspectiva do RCNEI o educar significa proporcionar situações de aprendizagens orientadas de forma que possam contribuir para as crianças desenvolverem as capacidades infantis e os conhecimentos, já na perspectiva do cuidar refere-se ao sentido de valorizar essas capacidades, compreendendo as crianças em suas especificidades.

Entretanto para que possa desenvolver esse trabalho de educar e cuidar com crianças de creche e préescola, várias questões precisam estar compreendidas, dentre elas o conhecimento do desenvolvimento infantil, conhecimento dessas potencialidades das crianças, espaços e materiais adequados, profissionais com uma formação necessária para planejar e desenvolver um trabalho que tenha como foco no desenvolvimento integral das crianças.

Sobre a participação dos alunos em jogos, todos os professores expuseram que eles participam e especificaram os momentos que essas atividades ocorrem. Os locais que os alunos mais participam de atividades lúdicas na escola são no momento da aula (100\%), seguido recreio (75\%) e nos momentos de entrada e saída da escola (50\%). Estes dados podem ser justificados, devido a observação no decorrer da aplicação do questionário foi possível observar mesmo de forma rápida pela pesquisadora que as aulas foram desenvolvidas com foco na recreação, onde as crianças brincam livremente, com poucas atividades dirigidas.

Continuando o questionário, buscamos conhecer dois relatos de jogos, no qual as professoras cotidianamente realizam e são vivenciados pelos seus alunos na creche. Podemos afirmar diante das respostas cedidas pelas pesquisadas, que suas respostas foram bem variadas. Algumas professoras utilizam o jogo para trabalhar conteúdos e assimilá-los de forma significativa e prazerosa para seus alunos. Nesse sentido ressaltamos a resposta cedida da Professora (P6) que afirmou: "Roleta de matemática, onde a criança associa o numeral à quantidade e encaixa o pegador. Centopeia dos números aonde a criança deve procurar o numeral que está faltando" (Quadro 10). A partir dessa resposta compreendemos que o jogo nessa situação pedagógica é utilizado com um objetivo de assimilar determinados conteúdos proposto pela professora.

Entretanto, outras professoras relataram nas suas respostas utilizar os jogos nas recreações. A Professora (P2) afirmou: "Circuito motor. Atividades Recreativas" (Quadro 10). A partir dessa resposta podemos compreender que esses jogos ou essas atividades recreativas propostas por essa professora não necessariamente é unicamente trabalhando conteúdo. Todavia, ressaltamos que mesmo de forma recreativa a atividade lúdica do jogo, estimula diversas habilidades das crianças, como psicomotricidade, socialização, afetividade dentre outras. 
Enfatizamos através dessa análise que nessas duas situações, trabalhando conteúdos ou atividades recreativas, se comprova os benefícios dos jogos. Abrangemos desse modo que a ludicidade vai ajudar aos professores a trabalhar tanto os conteúdos propostos, quanto ao mesmo tempo ajudar nas situações de recreações e socializações das crianças promovendo além do cognitivo, o desenvolvimento motor, afetivo e o social das crianças. Apesar de vivermos em uma era digital, não foi detectado nas falas das professoras nada referente aos jogos digitais, possivelmente, por se tratar de crianças de 0 a 3 anos de idade e/ou por conta da família não ter disponibilizado essas ferramentas para seus filhos ainda.

Quadro 10 - Relatos dos participantes da pesquisa sobre duas situações de jogos vivenciados em sua escola/creche. 2019

\begin{tabular}{|c|c|}
\hline Pesquisados & Falas dos Pesquisados \\
\hline P1 & "Amarelinhas e gincanas". \\
\hline $\mathbf{P 2}$ & "Circuito motor. Atividades Recreativas". \\
\hline P3 & "Jogos de encaixe e arremesso". \\
\hline $\mathbf{P 4}$ & $\begin{array}{c}\text { "Em sala, separamos os alunos em grupos e disponibilizamos jogos, na Brinquedoteca, os alunos escolhem } \\
\text { livremente e a professora auxilia". }\end{array}$ \\
\hline P5 & "Boliche, jogos educativos que envolvam noção e associação de figuras, noção de lugar e espaços". \\
\hline P6 & $\begin{array}{c}\text { "Roleta de matemática, onde a criança associa o numeral à quantidade e encaixa o pegador. Centopeia dos } \\
\text { números aonde a criança deve procurar o numeral que está faltando". }\end{array}$ \\
\hline P7 & "Quebra cabeça, peças de encaixe, jogos com bolas". \\
\hline P8 & "Jogos que envolva cores e numerais". \\
\hline
\end{tabular}

Corrobora sobre a importância dos jogos, com os estudos de Piaget (1971) que vem contribuir afirmando que o jogo, pode ser fundamental no desenvolvimento infantil da criança. $\mathrm{O}$ autor faz uma relação de jogo relacionando etapas do desenvolvimento, e enfatiza que inicialmente se tem o jogo de exercício, aquele em que a criança repete uma determinada situação puramente por prazer. Por volta de 2-3 e 4-5 anos, nota-se a ocorrência dos jogos simbólicos, onde a criança passa a não apenas relembrar os fatos acorridos e começa a executar representações. Já no período posterior, surgem os jogos de regras que são transmitidos socialmente de crianças para crianças e por pura consequência vai aumentando com o progresso e o desenvolvimento social dessas relações e do desenvolvimento da criança.

Já segundo Vygotsky (1998), o desenvolvimento humano vai acontecer durante todo o percurso da vida e as funções psicológicas vão ser construídas ao longo dela também, diferentemente de Piaget, ele não estabelece fases para explicar o desenvolvimento, vem esclarecendo que o "sujeito" é interativo, acreditando que a criança vai utilizar as interações sociais como formas privilegiadas de acesso as situações, de maneira que acabam aprendendo com os outros as regras do jogo, aprendem a regular seu próprio comportamento pelas reações e socializações com outras crianças. Consideramos que essas professoras mesclam variados tipos de jogos, trabalhando conteúdos ou jogos de recreação, e continuamos ressaltando que esses dois tipos de atividades podem desencadear saberes diversificados que promovem um conhecimento prazeroso, mesmo de forma recreativa a criança vai aprender.

Oliveira (2014, p. 160) também afirma que o brincar, o afeto, a motricidade, a linguagem, a percepção, a representação, a memória e além de outras funções cognitivas estão profundamente interligadas. Assim a criança tem possibilidade de construir novos conhecimentos nas relações que são estabelecidas com as outras nas atividades lúdicas, sejam essas atividades com jogos educativos ou atividades recreativas. 
Buscamos conhecer também no questionário, qual a opinião das participantes da pesquisa sobre o papel do professor nas situações do jogo. A partir das respostas cedidas pelas participantes, todas as professoras foram unânimes em afirmar que o papel do educador na situação do jogo é a de mediação (Quadro 11).

Diante de suas respostas podemos assegurar que o educador deve mediar essa ação como um incentivador. Nesse sentido destacamos a resposta da Professora (P5) que afirmou: "Organizar, mediar e oferecer espaços no dia a dia de momentos favoráveis no brincar que proporcione alegria, movimento e prazer" (Quadro 11).

Quadro 11. Opinião dos participantes sobre o papel do(a) professor(a) na situação de jogo. 2019

\begin{tabular}{|c|c|}
\hline Pesquisados & Falas dos Pesquisados \\
\hline P1 & "Mediador". \\
\hline P2 & "Facilitador e participante, junto ao aluno". \\
\hline P3 & "É de mediador, articulador e incentivador". \\
\hline P4 & "Intermediar os objetivos dos jogos". \\
\hline P5 & "Organizar, mediar e oferecer espaços no dia adia de momentos favoráveis no brincar que proporcione \\
\hline P6 & alegria, movimento e prazer". \\
\hline P7 & "Mediar à criança em determinadas situações". \\
\hline P8 & "Mediar e incentivar". \\
\hline
\end{tabular}

Recorremos nesse aspecto a Antunes (2003), que sugere que o professor deve atuar durante todo o processo de ensino-aprendizagem das crianças, exercendo a função de facilitador, como um mediador entre aluno e a construção de novos conhecimentos, o professor deve então estimular para que o aluno consiga estabelecer relações com a realidade que ele vivencia, e assim as crianças vão aos poucos incorporando as atividades lúdicas que são propostas ao processo de ensino-aprendizagem, o autor ainda esclarece e exemplifica que ação do jogo para a criança é de fundamental, pois o jogo vai despertar e motivar a criança, não apenas com instinto de divertimento, mas como uma fonte que contribui de forma positiva e enriquece o desenvolvimento intelectual do aluno.

Antunes (2003) ainda vem ressaltar que a relação existente nos jogos proporciona na criança uma aprendizagem significativa, ele explica que a escola não é necessariamente aquela que deve ter ou possuir uma quantidade enorme de caríssimos brinquedos ou jogos ditos educativos, mas o que se espera de fato da escola, é que ela possa realmente dispor de uma equipe de educadores que saibam como utilizar os recursos existentes, e que possam fazer uma reflexão sobre como o jogo pode despertar o interesse do aluno, que saibam pedagogicamente fazer de simples objetos naturais uma oportunidade de descoberta e exploração imaginativa para o mundo infantil.

Compreendemos assim que é preciso que os professores principalmente os da Educação Infantil repensem ou revejam o modo de suas mediações e práticas pedagógicas cotidianas, de forma que percebam a realidade e os contextos de onde as crianças estão inseridas e assim possam organizar suas propostas de trabalho voltadas para a ludicidade. Ressaltamos que a sociedade cobra muito desses profissionais, porém o educador é o elemento chave desse processo educacional, já que ele é o mediador da relação das crianças com os conhecimentos, assim os educadores devem continuar assumindo um papel essencial na Educação Infantil.

Dando continuidade ao questionário, procuramos conhecer a opinião das participantes da pesquisa sobre a importância do jogo para a educação. A partir das respostas cedidas pelas participantes da pesquisa no Quadro 12, podemos afirmar que as professoras enfatizaram vários benefícios e a relevância do jogo. Entretanto, notamos em 
todas as respostas que foram cedidas pelas professoras nesse quadro, que elas colocaram algo em comum nas suas respostas, elas exemplificaram que o jogo vai ajudar a criança a compreender o sentido das regras e aceitá-las da melhor maneira. Destacamos a resposta da professora (P7) que afirmou "É através do jogo que a criança é capaz de impor os elementos significativos e desenvolver sua capacidade de abstração e aceitação das regras" (Quadro 12). Percebemos assim que essas professoras compreendem a importância do jogo para a educação.

Quadro 12 - Opinião dos participantes sobre a importância do jogo para a Educação. 2019

\begin{tabular}{|c|c|}
\hline Pesquisados & Falas dos Pesquisados \\
\hline P1 & "É importante para determinar regras a serem cumpridas de forma divertida". \\
\hline P2 & "Favorece trabalhar seus limites e construir seus conhecimentos". \\
\hline P3 & "Além de desenvolver as habilidades psicomotoras e cognitivas, auxilia no cumprimento das regras". \\
\hline P4 & "O jogo é a primeira etapa para se alcançar o conhecimento, pois os alunos aprendem que devem \\
respeitar regras, fazer sequência e criam um esquema mental”.
\end{tabular}

Recorremos nesse sentido aos estudos de Vygotsky (1994) que vem contribuir esclarecendo que a criança que continuamente teve a oportunidade de vivenciar possibilidade de atividades lúdicas envolvendo especialmente os jogos, provavelmente vai ter mais probabilidade de saber trabalhar de forma mais harmônica em um ambiente coletivo, isso se justifica pelo pensamento que já se vivenciou em grupo jogos de regras, terá aprendido a aceitar as regras que foram estabelecidas nos jogos que vivenciou. Vygotsky (1991, p. 82) vem destacar que a criança que sempre participou de jogos e brincadeiras grupais saberá trabalhar em grupo; por ter aprendido a aceitar as regras do jogo, saberá também assim, respeitar as normas grupais e sociais. Assim na atividade do jogo, a criança vai compreender o devido motivo de aceitar e respeitar as regras, a importância da socialização, aprende aos poucos a ganhar e a perder, que são princípios fundamentais para a vida e para formação de sua personalidade.

Diante do exposto podemos entender que os jogos que são vivenciados nas atividades de grupos e no coletivo acolhem as crianças e elas têm uma maior possibilidade de aprender a trabalhar em equipe, passam a partir das experiências vivenciadas no coletivo a entender que a competição pode tornar-se um desafio prazeroso e alegre, e a superação para vencer torna-se um incentivo para realizar determinada ação, aprendendo que as regras existem para estabelecer uma ordem, e aprende também aos poucos que trabalhar em grupo é necessário, então a ação que o jogo possibilita é um meio de construção de saberes aliada a uma educação voltada para ludicidade.

No que diz respeito à presença da ludicidade na Educação Infantil, para isso deixamos um espaço no questionário, para que as professoras tivessem a oportunidade de oferecer possíveis sugestões ou propostas que pudessem ser destacadas para o nosso contexto da ludicidade com crianças pequenas. Suas respostas contribuíram para analisamos a prática existente da ludicidade nessa instituição e refletir sobre as sugestões propostas das professoras. Nesse sentido destacaremos a resposta cedida pela Professora (P3) que afirmou: "Melhorar as formações enfatizando atividades vivenciadas" (Quadro 13). Assim, é possível afirmamos que todas as pesquisadas desejam conhecer melhor e aprofundar a temática da ludicidade de forma que possam aprimorar seus 
conhecimentos atuais e adquirir novos, e que esses novos conhecimentos fossem vivenciados na prática e do cotidiano com as crianças. Elas almejam vivenciar experiências inovadoras.

Diante das sugestões que foram destacadas pelas participantes da pesquisa, ressaltamos uma resposta cedida pela Professora (P4) que sugeriu: "Material para utilizar... materiais que as crianças possam usar, sem medo de estragar" (Quadro 13). Ao analisar sua sugestão, logo podemos entender que é evidente a crítica feita por essa professora, afirmamos com essa resposta que a professora quis relatar a questão de matérias, justificando que a criança possa usar eles, sem medo de estragar, isso segundo sua resposta significaria assim que não serve de nada material pedagógico, caso a criança não possa utilizá-lo no seu cotidiano, mostrando que a criança deve usar sem medo de vir a estragar. Analisando ainda essa crítica dessa educadora, podemos considerar que toda prática envolvendo a ludicidade parte do princípio que a criança está em processo de aprendizagem e sendo assim ela vai aprender a utilizar os materiais junto com as medições feitas cotidianamente.

Quadro 13. Opinião dos participantes sobre a presença da ludicidade na Educação Infantil e possíveis sugestões que poderiam ser destacadas para tal contexto. 2019

\begin{tabular}{|c|c|}
\hline Pesquisados & Falas dos Pesquisados \\
\hline P1 & "A ludicidade na educação infantil é primordial sem ela a aprendizagem é defasada”. \\
\hline P2 & "Criar espaços e oportunidade para que as crianças se desenvolvam". \\
\hline P3 & "É necessário sensibilizar os professores para que possam inserir de forma sistemática, na prática”. \\
\hline P4 & "Material para utilizar... materiais que as crianças possam usar, sem medo de estragar”. \\
\hline P5 & "Primeiramente jogos variados”. \\
\hline P6 & "Jogos e brincadeiras deveriam trabalhar mais a questão do corpo, gestos, movimentos, sons". \\
\hline P7 & (Não respondeu). \\
\hline P8 & "Melhorar as formações enfatizando atividades vivenciadas". \\
\hline
\end{tabular}

Diante dessas argumentações, recorremos a Fonseca (1998) que contribui esclarecendo que todo o movimento humano é construído em função de alguma intenção e expressividade íntima, dessa forma o movimento realizado vai aos poucos se transformando em uma série de comportamentos que emergem significados. Então a partir das experimentações concretas e das manipulações que a criança vai se apropriando do meio em que está inserida comunicando-se, organizando-se e desorganizando-se, até chegar à construção visível enquanto sujeito.

Com isso é necessário considerarmos que as condutas das crianças não são apenas reações, são também experiências que podem ajudar a desenvolver suas atitudes no cotidiano, assim o professor deve analisar as condutas e comportamento tentando ajudar seus alunos a superar determinada ação ou atitude.

Oliveira (2011, p. 33), "vem reiterar nesse sentido afirmando que pouco a pouco, a criança começa a se expressar através dos gestos que estão ligados a esfera afetiva e que são o escape das emoções vividas". Dessa maneira podemos compreender que o professor vai ter a capacidade de moldar ou ajustar as ações e atitudes das crianças no convívio social, podendo assim contornar suas ações de modo mais apropriado, como também a execução dessas atitudes.

Entendemos dessa maneira que o objetivo que se deve alcançar necessita estar ligado a algo que se deseja trabalhar com as crianças, tendo em vista que as crianças estão em processos contínuos de desenvolvimento, assim quanto mais às crianças forem colocadas em situações nas quais elas tenham que repensar sobre o movimento, atitudes e ações que realizam consequentemente, elas irão reelaborar seus movimentos, fazendo com que sua cognição, organização motora e emocional sejam estimuladas, construídas e reconstruídas. Por isso, confirmamos 
que o aspecto afetivo tem fundamental importância na formação do intelecto de cada criança, assim, a ludicidade é um meio para que seja possível educar a mente e o corpo ao mesmo tempo.

Continuando a aplicação do questionário, procuramos conhecer as opiniões das participantes da pesquisa sobre possíveis contribuições acerca da ludicidade ao contexto escolar e que essas professoras citassem quais contribuições são vistas em seus alunos. A partir de suas respostas expostas no Quadro 14, podemos afirmar que a pesquisa evidenciou diversas contribuições em diferentes aspectos, tanto cognitivas, sociais, como motoras, que segundo as pesquisadas são essenciais para desenvolvimento das habilidades das crianças. Assim, a Professora (P6) que afirmou: "A criança se sente mais segura em relação para realizar diversas atividades, em um momento que ela já vivenciou aquela situação, ou atividade lúdica, assim ele vai desenvolver qualquer outra atividade com mais facilidade e segurança de si próprio" (Quadro 14).

Quadro 14. Opinião dos participantes sobre quais as contribuições da ludicidade para o contexto escolar. 2019

\begin{tabular}{|c|c|}
\hline Pesquisados & Falas dos Pesquisados \\
\hline P1 & "Sim, prazer por aprender/auxilia ao professor/ diminui a evasão escolar e ajuda na socialização". \\
\hline P2 & "Oportunidade para que as crianças se desenvolvam de forma integral”. \\
\hline P3 & "Vivencia prazer em participar das atividades. Torna significativo o trabalho". \\
\hline P4 & "Aumenta a percepção dos alunos, fazem compreender conteúdos de forma concreta como cores, \\
quantidades, etc".
\end{tabular}

Os estudos de Kishimoto (2010) vêm esclarecer que o lúdico é para a criança a oportunidade de desenvolvimento, pois amplia seus conhecimentos, já que nas atividades lúdicas são estimuladas além da curiosidade, a segurança e a autonomia, expande ainda mais a linguagem e a concentração, segundo o autor ilustra a ludicidade vai cooperar para que a criança se torne um adulto competente e mais equilibrado, ressaltando que as crianças aprendem muito mais se o conteúdo oferecido for por meio de atividades lúdicas. Assim o docente vai poder conduzir o conhecimento, necessitando de uma atividade lúdica adequada para seu público, exemplificando que é necessário fazer uma análise para que haja a seleção de materiais apropriados, de um espaço favorável para tal aula, necessitando também de se ter uma análise crítica em geral, para desenvolver tal atividade lúdica.

Maluf (2003, p. 29), também vem contribuir afirmando que o lúdico é o parceiro do professor, já que desenvolve habilidades e leva a criança a fazer novas descobertas através de suas experiências. Esclarece que o professor deverá aproveitar toda a riqueza que o lúdico oferece, envolvendo a fantasia do brincar, em diferentes contextos, desde faz-de-conta, da imaginação, contação de história, dramatização, a fim de promover novos conhecimentos, a autora vai enfatizar que a ação lúdica pode ser uma atividade espontânea bastante prazerosa, acessível a todo ser humano independente até de qualquer faixa etária, classe social ou condição econômica.

O lúdico não está unicamente ligado apenas à atividade do brincar, mais além de envolver uma vasta possibilidade de atividades psicomotoras, envolve também até no ato de ler, apropriar-se da compreensão do 
mundo com a leitura, atividades de expressão lúdicas de diversas maneiras, podem-se atrair a atenção das crianças, podendo construir mecanismos que potencializem o que se deseja alcançar na aprendizagem da criança.

Dando continuidade aos questionamentos, procuramos conhecer o entendimento das docentes acerca do tema "Pedagogia do lúdico" ou "Expressão lúdica" na intenção de conhecer o processo de suas formações iniciais. Analisando o Quadro 15 podemos afirmar que as respostas das participantes foram diversificadas, destacando-se para discussão duas respostas. A da Professora (P3) que afirmou: "Conclui pedagogia no ano de 2004 num regime especial (finais de semana) não me recordo de ter visto disciplinas relacionadas com a ludicidade". E a resposta da Professora (P4) que declarou: "Não tive muito aprofundamento, apenas uma explanação sobre" (Quadro 15). A partir de suas respostas evidenciamos que durante suas graduações não aprofundaram a temática da ludicidade. Entretanto, destacamos a resposta da Professora (P1) que afirmou: "Essas disciplinas foram fundamentais na prática, e deveria ser ampliada nas formações docentes cada vez mais" (Quadro 15), evidenciando que essa docente teve a possibilidade de vivenciar temas relacionados com a ludicidade durante sua graduação, lhe servindo de apoio até hoje nas suas ações educativas.

Quadro 15. Analise das participantes sobre seu entendimento dos termos "Pedagogia do lúdico" e "Expressão lúdica" no processo de formação profissional. 2019

\begin{tabular}{|c|c|}
\hline Pesquisados & Falas dos Pesquisados \\
\hline P1 & "Foram fundamentais na prática, e deveria ser ampliada nas formações docentes cada vez mais". \\
\hline P2 & "É pertinente, pois dará maior suporte a prática para realizar um trabalho em sala de aula". \\
\hline P3 & "Conclui pedagogia em 2004 em não me recordo de ter visto conteúdos relacionados com a ludicidade". \\
\hline P4 & "Não tive muito aprofundamento, apenas uma explanação sobre". \\
\hline P5 & "O aprofundamento é necessário e só enriquece nosso trabalho e desenvolvimento das crianças". \\
\hline P6 & (Não respondeu). \\
\hline P7 & "Não tive esses componentes. Porém dentro do componente em Educação Infantil citou o lúdico". \\
\hline P8 & "São essenciais". \\
\hline
\end{tabular}

Corsino (2009) sugere essencialmente a qualidade do atendimento para que haja a construção da identidade profissional, afirmando que é preciso que os profissionais da educação tenham oportunidades de reflexão que orientem o seu fazer pedagógico. Acreditando assim que é importante que os docentes possam mobilizar a experiência com a produção de saberes. Nesse sentido a formação continuada é uma alternativa para superar as dificuldades vivenciadas por essas professoras no cotidiano da creche, evidenciadas por elas no questionário. Diante disso, se faz necessário um novo pensar das práticas pedagógicas, uma mudança no caminho das habilidades apresentadas pelas crianças em todos os seus aspectos, sejam psicomotores, cognitivos, emocionais e até culturais.

Dando continuidade aos questionamentos, procuramos conhecer se as participantes da pesquisa, já participaram ou tiveram oportunidade de ter alguma discussão ou formação continuada no seu ambiente de trabalho sobre a Base Nacional Comum Curricular. E se sim, foi solicitado que essas professoras falassem sobre o objetivo dessa formação, e o descrevessem o que aprenderam sobre a base.

A partir do Quadro 16, destacamos inicialmente as respostas cedidas das professoras que não tiveram acesso a esse documento, que foram a Professora (P3) que não respondeu nenhuma das questões que se tratava da BNCC, no questionário, todas as questões relativas a base essa professora deixou em branco e avisou a pesquisadora que desconhecia desse documento, evidenciando assim que não tem conhecimentos sobre a Base ou possivelmente não teve formação sobre o mesmo. 
A Professora (P5) que também afirmou: “Ainda não, apenas alguns comentários entre colegas de trabalho”. Mostrando também que não participou de nenhuma formação, e não possui conhecimentos adequados acerca da BNCC. E por último ressaltamos a resposta cedida da Professora (P8) que também afirmou: "Não. Apenas pontos de discussões, que possivelmente teremos que colocar nos nossos planejamentos futuramente". Podemos então afirmar que as Professoras (P3), (P5) e (P8) não tiveram conhecimentos relevantes sobre a base no seu ambiente de trabalho. As demais professoras (P1), (P2), (P6) e (P7) relatam diante de suas respostas cedidas, terem ouvido falar sobre o documento. Porém enfatizamos que suas respostas evidenciaram que foram discussões superficiais, sem muito aprofundamento teórico sobre a Base Nacional Comum Curricular.

Quadro 16. Opinião dos participantes, sobre quais discussões ocorreram na escola/creche e/ou formação continuada sobre a BNCC. 2019

\begin{tabular}{|c|c|}
\hline Pesquisados & Falas dos Pesquisados \\
\hline P1 & "Informou sobre a importância de vivenciar a base nacional comum curricular em nosso municipio". \\
\hline P2 & "Adquirir maiores conhecimentos sobre a mesma, para aplicá-la com mais segurança no dia a dia da \\
escola".
\end{tabular}

A Base Nacional Comum Curricular (2015) propõe e nomeia cinco campos de experiências: o eu, o outro e o nós; corpo, gestos e movimentos; traços, sons, cores e imagens; escuta, fala, linguagem e pensamento; espaços, tempos, quantidades, relações e transformações. Os Campos de experiência de acordo com a BNCC (BRASIL, 2015, p. 21): Colocam no centro do projeto educativo, as interações, as brincadeiras, de onde emergem as observações, os questionamentos, as investigações e outras ações das crianças articuladas com as proposições trazidas pelos/as professores/as. Nesse sentido cada campo de experiência vai possibilitar e oferecer às crianças a oportunidade de interagir com pessoas, com objetos, em situações diversificadas, atribuindo um sentido pessoal e singular em cada um desses momentos.

Dessa maneira os conhecimentos que são organizados e reconhecidos pelo professor devem ser como fruto das experiências das crianças, devendo ser mediados para aprofundar as aprendizagens, por isso torna-se de grande importância que todos os professores, principalmente os da Educação Infantil, conheçam e tenham acesso a BNCC e se possível que existam formações sobre a BNCC para que entendam sobre o que se trata esse documento, e que possam compreender sobre os campos de experiências, e como eles são sugeridos.

Seguindo com o questionário, procuramos conhecer também qual a opinião das participantes da pesquisa sobre até que ponto a BNCC pode ou não contribuir de forma significativa para o desenvolvimento integral das crianças. A partir da observação e análise do Quadro 17, podemos afirmar que as professoras reconhecem o documento e sabem pouco sobre a Base Nacional Comum Curricular. Conhecem aquilo que é dito de forma global, sem muita apropriação adequada e com pouca compreensão do que realmente trata-se o documento, não conhecem de forma sólida o que a Base vem propor. De forma geral, suas respostas cedidas no Quadro 17, indicam que não 
compreendem o que é realmente proposto, afirmam que a BNCC vem contribuir sim para a Educação Infantil, porém ainda não conseguem expressar de forma adequada essas contribuições.

Para exemplificar essa argumentação ressaltamos a resposta cedida pela Professora (P1) que afirmou: “Assegurando uma educação comum”. A maioria das respostas das participantes da pesquisa se fundamenta nesse contexto, ou seja, a maioria das participantes sustenta que é apenas uma referência que deve ser seguida para todos, compreendendo uma educação comum para as crianças.

A partir de suas respostas podemos afirmar que essas professoras alegam conhecer e ter ouvido falar sobre a BNCC, entretanto, elas demonstram que o que sabem de fato, é que a Base é uma referência que deve ser seguida, como um roteiro ou um norte para todos da educação.

No entanto devemos ressaltar mais uma resposta do Quadro 17 na qual a resposta cedida pela Professora (P5) que demonstrou ter conhecimento sobre a Base, afirmando que: "A partir do momento que trabalhamos por campos de experiência nos aproximamos do mundo das crianças e damos um significado maior para sua aprendizagem assegurando os seus direitos”. A partir de sua resposta podemos assegurar que essa professora (P5) tem conhecimento sobre os campos de experiências propostos pela BNCC, demonstrando assim ter uma apropriação mais profunda sobre o assunto.

Diferente das outras respostas cedidas pelas professoras do Quadro 17 essa foi à única professora que justificou a importância da Base assegurando que os campos de experiências devem garantir os direitos das crianças de vivenciar em um aprendizado mais significativo, indicando assim ser uma das que mais reconhece, e sabe de forma mais apropriada sobre a BNCC.

Quadro 17. Opinião dos participantes sobre até que ponto a BNCC contribui de forma significativa para o desenvolvimento integral das crianças. 2019

\begin{tabular}{|c|c|}
\hline Pesquisados & Falas dos Pesquisados \\
\hline P1 & "Assegurando uma educação comum”. \\
\hline $\mathbf{P 2}$ & $\begin{array}{c}\text { "Garantindo o direito de brincar e aprender, visando uma educação de qualidade, que possa ir de } \\
\text { encontro aos interesses e necessidades da criança". }\end{array}$ \\
\hline P3 & "?" \\
\hline P4 & $\begin{array}{c}\text { "Ela traz formas de como empregar conteúdos, como uma referência na educação infantil, de forma } \\
\text { comum a todas as crianças, que se bem empregados as crianças terão uma formação completa durante } \\
\text { essa etapa, é uma base comum que deve ser seguida". }\end{array}$ \\
\hline P5 & $\begin{array}{l}\text { "A partir do momento que trabalhamos por campos de experiência nos aproximamos do mundo das } \\
\text { crianças e damos um significado maior para sua aprendizagem assegurando os seus direitos". }\end{array}$ \\
\hline P6 & $\begin{array}{c}\text { "Vem abordar uma referência e reafirmar a importância da integração entre educar e cuidar das } \\
\text { crianças, em relação à aprendizagem "... }\end{array}$ \\
\hline P7 & "A BNCC declara a criança como o centro". \\
\hline P8 & "Irá contribuir para o desenvolvimento educacional de forma que há uma referência (base)". \\
\hline
\end{tabular}

Referente ao conteúdo da BNCC (BRASIL, 2018) seu discurso vem admitir e defender que a base não pode ser vista ou considerada como um currículo. De acordo com o próprio texto, trata-se de um documento orientador como de fato uma referência para todas as instituições educacionais, sejam elas públicas ou privadas. Devemos então compreender que até 2017 as DCNEI eram utilizadas como uma referência para orientar o trabalho pedagógico realizado nas instituições de ensino da Educação Infantil, no entanto, a partir de 2018 esse trabalho vem sendo estimulado a ser observado a partir dos princípios e propostas segundo a BNCC, que vem tentar 
determinar as questões da qualidade e dos problemas educacionais, com o objetivo de oferecer subsídios para que todos recebam o ensino mínimo exigido para todos.

Devemos enfatizar que o percurso da BNCC desde início até o processo de sua aprovação abrangeu muitas tensões e questionamentos, e ainda tem gerado críticas, tanto positivas quanto negativas. Porém tem se configurando como uma das temáticas amplamente discutidas na conjuntura atual do nosso país, principalmente quando se refere às mudanças no currículo da Educação Infantil, em alguns momentos é criticada e defendida por diferentes teóricos, defendida pela necessidade da sua existência, que traria inúmeros benefícios para todas as crianças e adolescentes, trazendo assim uma implicação de um trabalho em rede nacional. Dentre as críticas, vale ressaltar que a última versão apresentou na sua proposta de direitos de aprendizagem e desenvolvimento divididos em campos de experiência e subdivididos em faixas etárias de acordo com a idade, gerando inúmeras críticas por evidenciar uma divisão rígida das idades pelas crianças, as críticas se fundamentavam alegando que isso poderia vir a favorecer o fortalecimento da ideia de etapas rígidas de aprendizagens na educação infantil, vistas antigamente no cenário educacional, assim se faz necessário aprofundar a temática em questão.

As DCNEI para a Educação Infantil (BRASIL, 2009) divergem nesse sentido da BNCC, mostram-se não estabelecer faixas etárias para as crianças, fazendo referências para pensarmos amplamente os direitos das crianças de zero até seis anos, em uma educação de qualidade, sem homogeneizar as propostas curriculares nas diferentes instâncias do nosso país, essa proposta atual da BNCC-EI poderia implicar em uma alfabetização precoce para as crianças da Educação Infantil segundo críticas. Portanto, a criação de uma base fortaleceria uma educação nacional de forma igualitária.

Procurou-se conhecer qual conceito que as participantes da pesquisa apresentam, sobre como as brincadeiras são oferecidas nos campos de experiências da BNCC, tendo em vista as interações, os objetivos de aprendizagens e desenvolvimento no contexto da Educação Infantil. No Quadro 18 é possível conferimos que a Professora (P3) não respondeu novamente à pergunta, sobre a BNCC, evidenciando deste modo não ter domínio suficiente para comentar e explanar sobre a BNCC. A Professora (P5) que também deixou sua resposta em branco, provavelmente também não se sentiu preparada para responder, ou não tem informação necessária para explicar sobre os campos de experiências. E por último a resposta cedida pela professora (P7) que também afirmou: "Não me recordo". Essas três respostas destacadas comprovam que tais professoras demonstram não ter conhecimento adequado sobre os campos de experiências propostos pela BNCC, a pesquisa evidenciou a necessidade que essas professoras têm de aprofundar e conhecer melhor sobre esse documento.

Isso implica a necessidade de mais formações, debates, palestras e discussões sobre a base, que mesmo sendo aprovada, a pesquisa mostrou que na realidade são poucos professores que tiveram oportunidade de conhecer suas propostas, dessa maneira precisamos aprofundar essas informações da BNCC, para que possamos ter conhecimento e podemos assim dialogar e perceber até que ponto a base pode ou não favorecer o ensino e contribuir nas práticas pedagógicas dos profissionais da educação.

Quadro 18- Opinião dos participantes sobre como as brincadeiras são apresentadas nos campos de experiência da BNCC. 2019 


\begin{tabular}{|c|c|}
\hline $\mathbf{P 1}$ & "São de fundamental importância para o desenvolvimento das crianças". \\
\hline $\mathbf{P 2}$ & $\begin{array}{c}\text { "Como uma forma de explorar o mundo e o espaço ao seu redor. } \grave{A} \text { medida que estabelece relação consigo } \\
\text { mesma e com o outro". }\end{array}$ \\
\hline $\mathbf{P 3}$ & "?" \\
\hline $\mathbf{P 4}$ & "Como forma de vivenciar desafios e sentirem-se provocadas a resolvê-los, construindo significados". \\
\hline P5 & (Não respondeu) \\
\hline P6 & "Almeja que aprendizagem ocorra de uma forma prazerosa e significativa para as crianças". \\
\hline P7 & "Não me recordo" \\
\hline P8 & “Sim”. \\
\hline
\end{tabular}

Ao recorremos a BNCC, temos que compreender que ela organiza os objetivos de aprendizagem, considerando três subgrupos etários. Bebês (0-1 ano e seis meses), Crianças bem pequenas (1 ano e 7 meses a 3 anos e 11 meses) e Crianças pequenas ( 4 anos a 6 anos e 2 meses) defendendo seis direitos de aprendizagem que são: Conviver, Brincar, Explorar, Participar, Comunicar e Conhecer-se. De forma geral não é realmente apenas um documento que ordena o que deve ou não ser ensinado, ele vai situar a necessidade e o que deve ser direito comum a todas as crianças em qualquer escola do nosso país.

A BNCC vem de certa forma trazer também um discurso atualizado das DCNEI, entretanto, tendo como eixo de sua proposta as brincadeiras e as interações, assim por meio das experiências das crianças, os campos de experiências vão se articulando tendo como foco principal as experiências, não as atividades.

Sargiani (2016) defende que o papel da Educação Infantil deve ser o de garantir espaço para que a criança consiga ter aquisição das habilidades básicas, facilitando assim seu percurso na Educação Infantil de forma adequada e quando chegar sua ruptura dessa fase inicial para a fase de ensino fundamental sistemático, tudo possa ocorrer de forma que seja facilitado esse processo. Assim o autor defende que o desenvolvimento não inclui apenas os direitos das crianças de brincarem e de vivenciarem sua infância, mas pelo contrário, devem garantir o acesso igualitário de interação, compreensão das informações, desde a leitura e escrita, até de forma que promova simultaneamente a autonomia, desenvolvimento de potencialidades, diminuindo assim, as diferenças individuais, culturais e socioeconômicas existentes na nossa sociedade.

No Quadro 19 verificamos a partir das respostas das participantes que elas compreendem o uso das brincadeiras de forma positiva e construtivas para o desenvolvimento das aprendizagens das crianças, entretanto, devemos ressaltar que evidenciamos que quando tentam relacionar o documento da BNCC a essas vivências não conseguem fazer relação a partir dos seus próprios conhecimentos.

Podemos afirmar então que essas professoras não conseguem fazer uma relação conjunta com a base. Enfatizamos que todas as professoras conhecem o benefício das práticas lúdicas, das interações e experiências, porém não conseguem relacionar com o conteúdo existente e proposto pelo documento da BNCC, isso se justifica devido esse documento ter sido aprovado recentemente, devido a isso muitos professores ainda não tiveram acesso ou até mesmo a oportunidade de conhecê-lo melhor.

A BNCC apresenta um pouco das concepções das DCNEI (2009) e permite a reflexão sobre as práticas e posturas docentes na Educação Infantil, propondo que o professor se torna um colaborador, participante, garantindo através da organização de tempos, espaços e materialidades, muitas explorações para as crianças, possibilitando aprendizagens e descobertas com bebês e crianças bem pequenas e pequenas. 
Partindo desse pressuposto é preciso entender que a criança aprende brincando e para isso é necessário que as interações com as outras crianças e com os adultos sejam realizadas em diversas situações no ambiente escolar.

Quadro 19. Opinião dos participantes sobre sua compreensão e como avalia as propostas da BNCC, sobre o uso das brincadeiras e interações na Educação Infantil. 2019

\begin{tabular}{|c|c|}
\hline Pesquisados & Falas dos Pesquisados \\
\hline P1 & $\begin{array}{c}\text { "Na educação infantil, o desenvolvimento se dá por meio das brincadeiras. A BNCC apresenta o brincar como } \\
\text { um direito de aprendizagem sendo aplicada como forma educativa". }\end{array}$ \\
\hline P2 & $\begin{array}{c}\text { "Positivas, desde que sejam efetivamente promovidas oportunidades para que as crianças possam vivenciar o } \\
\text { lúdico na vivencia escolar". }\end{array}$ \\
\hline P3 & "?" \\
\hline P4 & "São boas, pois amplia as experiências dos alunos e seus conhecimentos". \\
\hline P5 & "É uma proposta bem pertinente. Que se fazem necessários para um bom desenvolvimento da criança". \\
\hline P6 & "Suas propostas são avaliadas e prazerosas tanto para o professor com para as crianças". \\
\hline P7 & "A criança deve ser livre para se expressar através das brincadeiras propostas". \\
\hline P8 & $\begin{array}{l}\text { "Avalio de forma positiva. Assim todas as crianças o direito de aprendizagens a seu favor. Favorecendo seu } \\
\text { desenvolvimento, não importando em que região ela esteja”. }\end{array}$ \\
\hline
\end{tabular}

Corrobora nesse sentido Vygotsky (1994) que vem ressaltar o valor da brincadeira para o processo do desenvolvimento da criança, defendendo que é através da brincadeira que a criança vai conseguir aprender a agir de forma cognitiva utilizando várias motivações internas, assim as brincadeiras se configuram como uma fonte rica de desenvolvimento infantil. Para Vygotsky (1994, p. 124) se o brinquedo é realmente a realização na brincadeira das tendências que não podem ser imediatamente satisfeitas, então os elementos das situações imaginarias constituirão automaticamente, uma parte da atmosfera emocional do próprio brinquedo. Ele vem esclarecer que a ação de brincar é uma atividade puramente construída pela própria criança nas suas interações. Ela vai estabelecer com o meio uma ligação demonstrando seus desejos e motivações, é assim por meio das brincadeiras que a criança conduz seu comportamento, não apenas pela percepção imediata dos objetos ou pela situação que afeta de imediato, mas pelo significado dessa situação.

Segundo Kishimoto (2010), todo o período da Educação Infantil é importante para a introdução de brincadeiras, e é por meio dessas que a criança constrói significados sobre si, os outros e sobre o mundo social. É sobre esse viés que são defendidos os campos de experiência da BNCC devem estabelecer em seus objetivos de aprendizagem e desenvolvimento, a inserção das brincadeiras fazendo com que diversas situações de aprendizagem sejam oportunizadas no espaço escolar, propiciando formas de interação, vivência, exploração, considerando principalmente as vivências e brincadeiras, como ponto de partida para a aprendizagem e de desenvolvimento de vários aspectos da criança.

\section{CONSIDERAÇÕES FINAIS}

Diante dos dados obtidos traçarmos o perfil social dos pesquisados e constatamos que todas as professoras são do sexo feminino. Identificamos apenas uma professora que não concluiu a graduação. Todas as demais possuem mais de 10 anos de experiência atuando na área da educação e possuem formação em pedagogia, verificamos também que duas professoras possuem formação acadêmica em outras áreas. 
As participantes da pesquisa utilizam a ludicidade como ferramenta pedagógica, e a maioria das educadoras abrangem a ludicidade nas suas práticas pedagógicas de forma direcionada com intuito de desenvolver atividades, relacionando os conteúdos que precisam ser assimilados pelas crianças, podemos afirmar que as professoras fazem suas mediações durante as brincadeiras direcionadas.

Consideramos que as participantes da pesquisa compreendem claramente o que é ludicidade e sua importância para o desenvolvimento e aprendizagem no processo de ensino, podemos assegurar que essas professoras reconhecem a importância do lúdico em suas práticas pedagógicas, mesmo muitas vezes não tendo sido enfatizado em sua formação. Para essas docentes as atividades lúdicas auxiliam no aprendizado e no desenvolvimento de seus alunos, contribuindo para a interação em diversos contextos, levando em consideração a aceitação das regras, o convívio social e as socializações. A maioria das pesquisadas alegam que promovem diversas atividades lúdicas, todavia há a necessidade de um trabalho mais coletivo, necessitando dos educadores uma análise e planejamento dessas atividades lúdicas.

A instituição que os professores lecionam, em relação ao espaço físico, é adequada, tem muito espaço para as crianças realizarem inúmeras atividades, tanto em sala de aula, como no próprio ambiente da instituição, com relação aos materiais pedagógicos, notamos dificuldades na aquisição dos mesmos, pelo fator custo, as professoras demonstram anseio por materiais variados para desenvolver aulas e atividades mais dinâmicas com seus alunos. Devemos destacar também que a creche não possui documentos oficiais, tais como, o Projeto Político Pedagógico (PPP) e nem Regimento Escolar.

Diante dos dados pode-se caracterizar a atuação profissional dos pesquisados quanto ao conhecimento e uso das orientações presentes na BNCC (Base Nacional Comum Curricular), verificou-se que essas professoras, não tiveram contato ou conhecimento efetivo com esse documento, evidenciamos na pesquisa que essas professoras não tiveram em sua instituição nenhuma formação específica que esclarecessem sobre a base, não conseguem apontar a necessidade ou a importância de se ter uma base. Entendem que é um documento que dever ser seguido, no entanto não compreendem seus princípios norteadores, não conhecem seus campos de experiência, podemos afirmar que essas professoras ainda não estão preparadas para lidar com as propostas e com os desafios exigidos pela Base, não possuem conhecimento de maneira satisfatória para utilizar e colocar em suas práticas pedagógicas, ainda não norteia seus planos de aula ou planejamentos na perspectiva da BNCC.

A maioria das professoras conhece muito pouco a respeito da BNCC, para essas educadoras é algo novo, chegou para esses profissionais sem nenhuma formação, apenas discussões entre colegas de profissão. Asseguramos que essas professoras definem a Base como uma espécie de currículo, diferentemente do sentido real da BNCC. As participantes da pesquisa ressaltaram ser importante ter uma base, mesmo não conhecendo o documento, acreditam que com uma Base Comum para todas, as diferenças sociais e econômicas do nosso país poderiam ser resolvidas ou amenizadas.

Pode-se concluir que foram positivas e de grande importância para essa pesquisa todas as considerações apontadas pelas professoras, nos permitiram entender até que ponto as abordagens teóricas têm servido de apoio para a prática pedagógica dessas professoras, suas contribuições também ajudaram a analisar a importância da 
ludicidade no processo de ensino/aprendizagem. Entretanto, é viável esclarecer que apenas uma pesquisa não é o suficiente para chegarmos a conclusões e por isso evidenciamos a necessidade de que outras pesquisas sejam desenvolvidas nessa área. Podemos considerar essa pesquisa como uma pequena amostra.

\section{REFERÊNCIAS}

ANTUNES, I. Aula de português: encontro \& interação. Parábola ed., 2003.

BRASIL. Ministério da Educação. Base Nacional Comum Curricular - BNCC. Brasília, DF, 2018.

. Ministério da Educação. Base nacional comum curricular. Brasília, DF: MEC, 2015. Disponívelem:

<http://basenacionalcomum.mec.gov.br/documento/BNCC-APRESENTACAO.pdf>. Acesso em: 28 fev. 2020.

. Parecer CNE/CEB no 20/2009 e Revisão das Diretrizes Curriculares Nacionais para a Educação

Infantil. Brasília, 2009.

FALCÃO, A. P. B.; RAMOS, R. O. A Importância do brinquedo e do Ato de Brincar para o desenvolvimento psicológico de crianças de 5 A 6 anos. Belém, 2002.

FONSECA, V. Aprender a aprender: a educabilidade cognitiva. 1998.

KRAMER, S. Com a pré-escola nas mãos: uma alternativa para a educação infantil. São Paulo: Ática, 2009.

KISHIMOTO, T. M. Brinquedos e brincadeiras na educação infantil. BRASIL. Ministério da Educação e da Cultura, Conselho Nacional de Educação, Câmara de Educação Básica, 2010.

LEFÈVRE, F.; LEFEVRE, A. M. C. Depoimentos e discursos: uma proposta de análise em pesquisa social. In: Depoimentos e discursos: uma proposta de análise em pesquisa social. 2005.

MALUF, A. C. M. Brincar, prazer e aprendizado. Petrópolis, RJ: Vozes, 2003.

MATOS, E. S. Identidade profissional docente e o papel da interdisciplinaridade no currículo de licenciatura em computação. Revista Espaço Acadêmico, v. 13, n. 148, p. 26-34, 2013.

MOYLES, J. R. Só brincar? O papel do brincar na Educação Infantil. Porto Alegre: Artmed, 2002.

OLIVEIRA, D. R. A formação continuada de professores de primeiro ano do ensino fundamental de nove anos e os desafios ao trabalho pedagógico. 2011.

OLIVEIRA, Z. M. R. Educação Infantil: fundamentos e métodos. Cortez Editora, 2014.

ORLANDI, E. P. Análise de discurso: princípios e procedimentos. Campinas: Pontes, 1999.

PIAGET, J.; ÁLVARO C.; OITICICA, C. M. A formação do símbolo na criança: imitação, jogo e sonho, imagem e representação. 1971.

PIAGET, J. A formação do símbolo na criança. Rio de Janeiro: Guanabara Koogan, 1978.

. Para onde vai à educação? Rio de Janeiro: Livraria José Olympo Editora/Unesco, 1973.

SARGIANI, R. A. Fases iniciais da aprendizagem da leitura e da escrita em português do Brasil: efeitos de fonemas, gestos articulatórios e sílabas na aquisição do mapeamento ortográfico. 2016. 215 f. Tese (Doutorado em Psicologia). Universidade de São Paulo, São Paulo, 2016.

VIGOTSKY, L. A formação social da mente. São Paulo: Martins Fontes, 1994.

WAJSKOP, G. O brincar na educação infantil. Cadernos de pesquisa, n. 92, p. 62-69, 1995.

YIN. R. K. Estudo de caso: planejamento e métodos. 3. ed. Porto Alegre: Bookman, 2005. 